\title{
Primary pulmonary sarcoma - treatment outcomes depending on the different types of radical operation
}

\author{
Janusz Gołota ${ }^{1}$, Karolina Osowiecka², Tadeusz Orłowski ${ }^{3}$ \\ ${ }^{1}$ Thoracic Surgery Clinical Ward, Municipal Polyclinic Hospital, Olsztyn, Poland \\ ${ }^{2}$ Depatment of Public Ward, University of Warmia and Mazury, Olsztyn, Poland \\ ${ }^{3}$ Department of Surgery, Institute of Lung Diseases and Tuberculosis, Warsaw, Poland
}

Kardiochirurgia i Torakochirurgia Polska 2019; 16 (1): 1-6

\begin{abstract}
Introduction: Primary pulmonary sarcomas (PPS) are rare types of non-epithelial malignant tumors of the lungs (0.013-1.1\% of all malignant lung tumors). The PPS can originate from mesenchymal elements of the bronchial wall, vessels or pulmonary stroma. Since the introduction of immunohistochemical and molecular diagnosis, a significant improvement in description and classification of sarcomas has been achieved. Nonetheless, sarcomas still remain a diagnostic and clinical problem.

Aim: To estimate factors which could have an influence on the overall survival (OS) and progression-free survival (PFS) of different types of radical operations $\left(R_{0}\right)$ for PPS.

Material and methods: Fourteen patients who underwent surgical radical treatment between 1994 and 2009 with a final diagnosis of PPS were analyzed.

Results: A group of 14 patients, treated with $R_{0}$ operations (pneumonectomies, lobectomies, non-anatomical resections), were included in the analysis. Median OS of patients undergoing $R_{0}$ operations was respectively: for pneumonectomy 7 months, lobectomy 20 months, non-anatomic resections 213 months. Patients subjected to non-anatomical resections had better prognosis than the others treated radically $(p<0.05)$; however, this group of patients had the most local recurrences (3 patients - 50\%). Statistical analysis did not show the influence of prognostic factors characteristic of PPS and soft tissue sarcoma (STS) on OS in the types of surgery performed.

Conclusions: There are no unambiguous factors affecting OS and PFS of patients who have undergone anatomical and nonanatomical resections. A large number of local recurrences in non-anatomical operations may indicate that PPS spread like lung cancer.
\end{abstract}

Key words: primary pulmonary sarcomas, non-anatomical resection, overall survival.

\section{Streszczenie}

Wprowadzenie: Pierwotne mięsaki płuca (PMP) to rzadkie typy nienabłonkowych nowotworów złośliwych płuc (0,0131,1\% wszystkich nowotworów złośliwych płuc). Mogą pochodzić z mezenchymalnych elementów ściany oskrzeli, naczyń lub zrębu płucnego. Od czasu postępu w diagnostyce immunohistochemicznej i molekularnej uzyskano znaczną poprawę w opisie i klasyfikacji mięsaków. Nadal jednak stanowią one trudne wyzwanie diagnostyczne i kliniczne.

Cel pracy: Określenie czynników, które wpływają na przeżycie całkowite (OS) pacjentów poddanych różnym typom operacji radykalnych $\left(R_{0}\right)$ w PMP.

Materiał i metody: Analizą objęto 14 pacjentów leczonych radykalnie w latach 1994-2009 z powodu PMP ustalonego w ostatecznym rozpoznaniu.

Wyniki: W grupie 14 pacjentów wykonano operacje z marginesem wolnym od choroby $\left(R_{0}\right)$. Były to pneumonektomie, lobektomie, resekcje nieanatomiczne. Mediana OS chorych poddanych $\mathrm{R}_{0}$ wyniosła odpowiednio: dla pneumonektomii - 7 miesięcy, lobektomii - 20 miesięcy, resekcji nieanatomicznych - 213 miesięcy. Pacjenci poddani resekcjom nieanatomicznym rokowali lepiej niż pozostali leczeni radykalnie, jednak w tej grupie pacjentów było najwięcej wznów miejscowych (3 pacjentów, 50\%). Analiza statystyczna nie wykazała wpływu czynników prognostycznych charakterystycznych dla PMP i mięsaków tkanek miękkich (MTM) na OS w przeprowadzonych typach operacji.

Wnioski: Nie zostały określone jednoznaczne czynniki, które wpływają na OS pacjentów poddanych resekcjom anatomicznym i nieanatomicznym. Duży odsetek wznów miejscowych w operacjach nieanatomicznych może świadczyć, że PMP szerzą się podobnie jak rak płuca.

Słowa kluczowe: pierwotne mięsaki płuca, resekcja nieanatomiczna, całkowite przeżycie.

Address for correspondence: Janusz Gołota MD, Thoracic Surgery Clinical Ward, Municipal Polyclinic Hospital, 44 Niepodległości St, 10-044 Olsztyn, Poland, phone: +48 510087 490, e-mail: januszgolota@vp.pl

Received: 13.09.2018, accepted: 27.12.2018. 


\section{Introduction}

Primary pulmonary sarcomas (PPS) are a diverse group of rare non-epithelial malignant tumors that develop from mesenchymal tissue of the lung, so originate from mesenchymal elements of the bronchial wall, vessels or pulmonary stroma. Lung sarcomas constitute only $0.013 \%$ to $1.1 \%$ of all malignant lung tumors [1-6]. In treatment of these cancers, the best results are achieved in radical surgical treatment. Confirmed prognostic factors in sarcomas are: size of primary tumor, histological type, histological grade $(G)$, grade TNM of lung cancer, and surgical margin (R) [1-6]. None of the published analyses indicates which factors may affect the survival after surgery, depending on the different types of radical operations $\left(R_{0}\right)$ for PPS.

\section{Aim}

The aim of the study was to estimate factors which could influence overall survival and progression-free survival of different types of $R_{0}$ resection in PPS.

\section{Material and methods Materials}

Fourteen patients with PPS treated with radical surgery $\left(R_{0}\right)$ at the Surgical Clinic of the Institute of Tuberculosis and Lung Diseases in Warsaw (IGiChP) between January 1994 and December 2009 (16 years) were included in this study. The analysis included all patients who were operated on for the first time between January 1994 and 16 October 2016. Patients were not treated with induction or neoadjuvant therapy. In case of recurrence patients were treated in the Maria Sklodowska-Curie Institute of Oncology in Warsaw (CO-I). The time of patients' observation ranged from 1 to 213 months (median time: 23 months). Patients with lesions in lungs which were metastases from other locations and patients with metastases in other organs identified at baseline were excluded from the analysis.

\section{Methods}

The analysis included an interview, a physical examination, the results of laboratory tests, results of diagnostic imaging as X-ray (RTG), ultrasonography (USG), computed tomography $(C T)$, magnetic resonance imaging (MRI), bronchofiberoscopy (FOB), scope of surgical treatment, histopathological diagnosis, adjuvant therapy and clinical observations. Histopathological analysis was carried out at the Department of Pathomorphology of the IGiChP and Pathology of the CO-I Department. Surgical specimens were assessed using hematoxylin and eosin $(H+E)$ staining, supplemented by immunohistochemical reactions. Grade of malignancy was determined in accordance with the $3^{\text {rd }}$ edition of the WHO classification of soft tissue sarcoma (STS) and the $7^{\text {th }}$ edition of the TNM classification of lung cancer.

\section{Statistical analysis}

Overall survival (OS) and progression-free survival (PFS) were estimated using the Kaplan-Meier method, and the statistical significance of the differences between curves was assessed using the log-rank test. In order to examine the differences between individual prognostic factors, depending on the applied resection technique, the $\chi^{2}$ test and the Fisher test (for qualitative variables) and the KruskalWallis test (for quantitative variables) were used. For statistical significance $p$-value $<0.05$ was applied. Statistical analysis was performed using the Statistica program (version 13) (StatSoft, Poland) (Table I).

\section{Results}

The study included 22 patients in the span of 16 years (from 1994 to 2009) who were diagnosed with primary pulmonary sarcoma (PPS) in the final histopathological diagnosis. The analyzed group of 22 [7] patients with PPS was $0.089 \%$ of the group of all operated patients and $0.506 \%$ of patients operated on because of lung cancer. In 8 out of 22 patients ( $36 \%, n=22$ ) locally advanced, inoperable form was primarily identified. In 2 (9\%) of these patients treatment was limited to insertion of a bronchial stent. Resections $\left(R_{0}\right)$ were carried out in 14 (63.6\%) patients. Resections included pneumonectomy in $4(18 \%)$ patients, lobectomy in 4 (18\%) patients - in 1 (4.5\%) of these patients expanded by resection of the atrium and in $6(27 \%)$ patients non-anatomical resection (6 patients, $42 \%$ ) -5 wedge resections and in one case tumor excision.

Patients treated radically were within the age range 2870 years (mean: $49.7 \pm 12.2$ ). This group consisted of $6(43 \%)$ men and 8 (57\%) women. The size of the tumor was $1-22 \mathrm{~cm}$ (7.5 \pm 6.3$)$. Seven histological types were determined: malignant fibrous histiocytoma (MFH) (3 patients, 21\%), leiomyosarcoma (3 patients, 21\%), peripheral primitive neuroectodermal tumor (PNET) (2 patients, 14\%), synovial sarcoma (2 patients, 14\%) and single cases of liposarcoma, malignant peripheral nerve sheath tumor (MPNST), hemangiopericytoma, and hemangioepitheliocytoma. The stage of disease according to the $3^{\text {rd }}$ edition of the STS classification was IA-III, and according to the $7^{\text {th }}$ edition of TNM lung tumor classification was T1NO-T4NO. The degree of histological malignancy was G1-3. Forced expiratory volume in 1 second $\left(\mathrm{FEV}_{1}\right.$ ) and vital capacity (VC) was $50-70 \%$. FEV 1 /VC was 60-102 (mean: 87.3 \pm 13.9 ).

Median overall survival (OS) of patients treated with $R_{0}$ resections was 27 months, in the case of anatomical resections 43 months and in the case of non-anatomical resections 213 months. Five-year OS of patients treated with $\mathrm{R}_{0}$ resections was $43 \%$, anatomical resections was $12 \%$ and non-anatomical resections was $83 \%(p=0.004)$ (Fig. 1).

Median overall survival of patients treated with pneumonectomy was 7 months, for lobectomy 20 months, for non-anatomical resections 213 months. Significantly better 5-year overall survival of patients treated with nonanatomical resections was observed in comparison with patients treated with lobectomy (respectively $83 \%$ vs. $25 \%$; $p=0.03)$ and pneumonectomy $(p=0.014)$. None of the patients who underwent pneumonectomy and lobectomy 


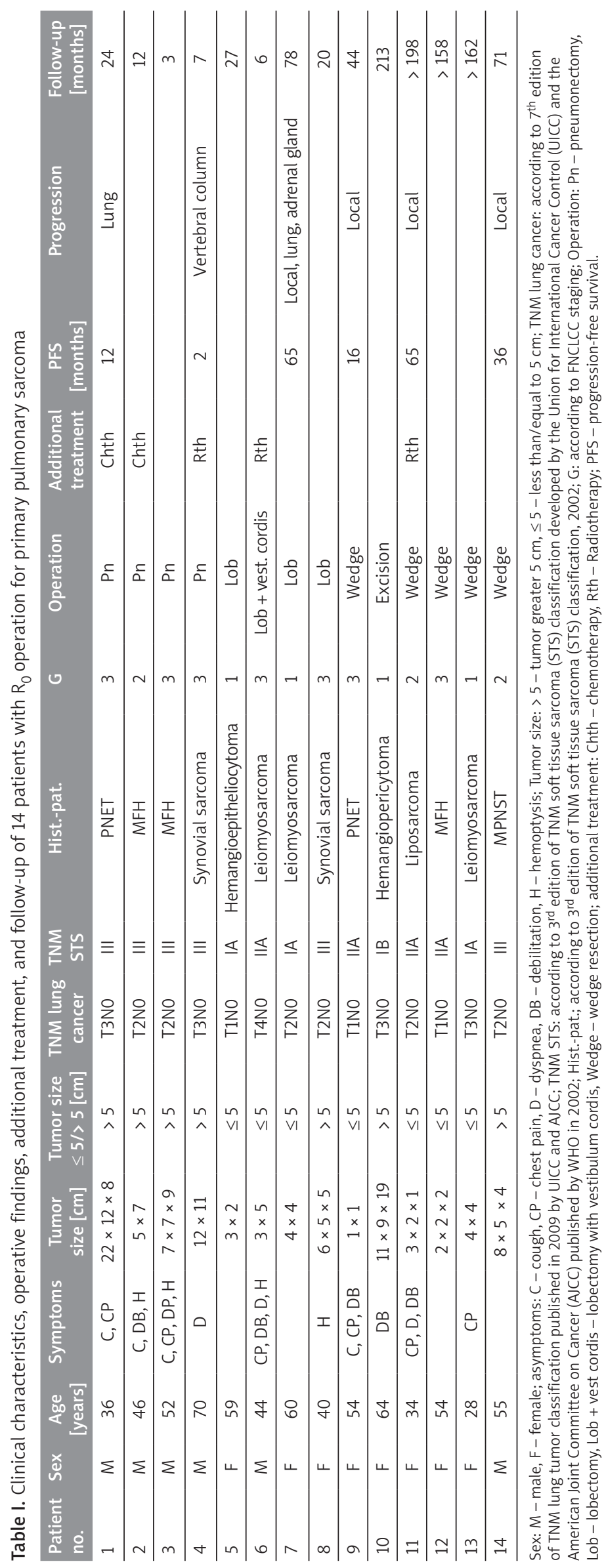

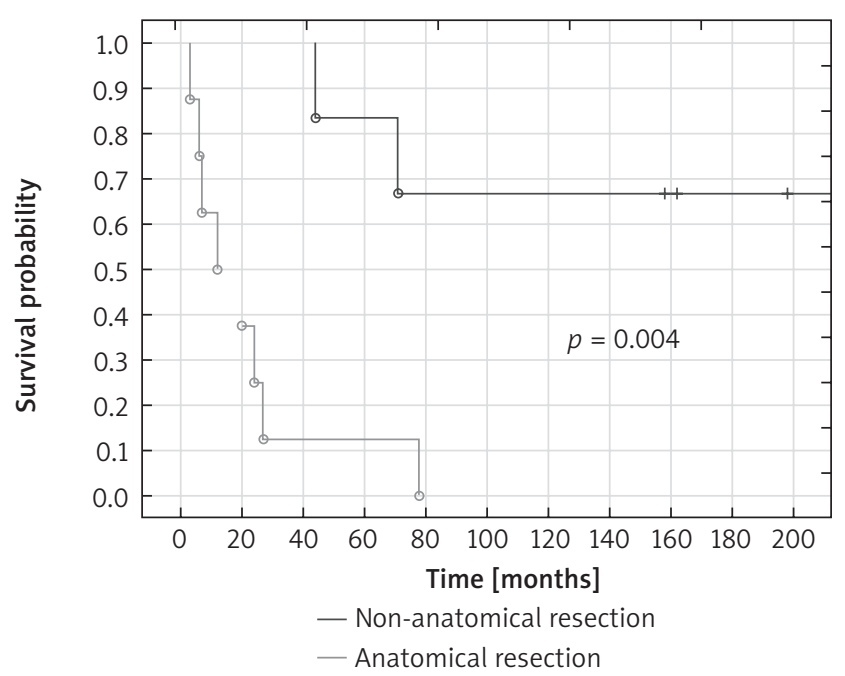

Fig. 1. Overall survival of patients treated with non-anatomical and anatomical resections

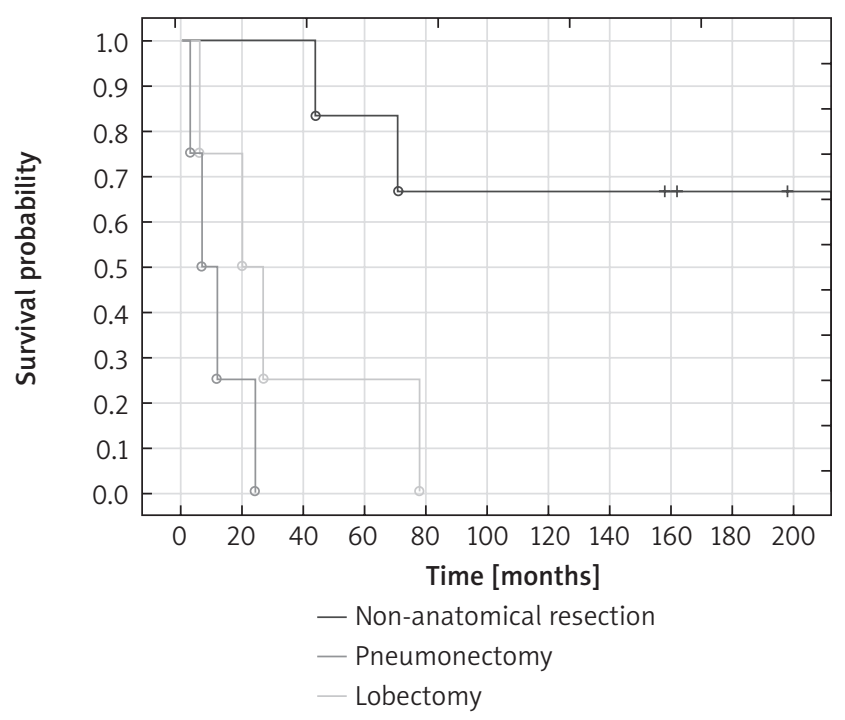

Fig. 2. Overall survival of patients treated with non-anatomical resections, pneumonectomy and lobectomy

survived 10 years. Ten-year overall survival of patients treated with non-anatomical resections was 67\% (Fig. 2).

There were no statistically significant differences in distribution of predictive factors between compared types of resection (pneumonectomy vs. lobectomy vs. non-anatomical resection) apart from sex (all men were treated with pneumonectomy, in other types of resection most patients were women). Patients who received pneumonectomy were the youngest in this analysis (36-70, median: 49 years). All of them were men, with tumor size $>5 \mathrm{~cm}$ (7-22, $10.5 \mathrm{~cm})$, stage of disease III according to the STS classification, degree of malignancy G2-3 (75\% of patients with $\mathrm{G} 3$ degree). In most patients (75\%) the duration of symptoms was longer than 3 months. The MFH was observed in half of the patients. Progression of disease occurred in the form of second lung or spine metastases. FEV 
and VC $70-100 \%$ were noted in respectively $50 \%$ and $75 \%$ of patients treated with pneumonectomy. All patients had endobronchial lesions observed in FOB.

In the case of lobectomy and non-anatomical resection, most patients were women, with tumor size $\leq 5 \mathrm{~cm}$ (median: $4.5 \mathrm{~cm}$ and $3.5 \mathrm{~cm}$ for respectively lobectomy and nonanatomical resection) and had a lower stage of disease according to the TNM STS classification in comparison with pneumonectomy group. Patients treated with lobectomy were 40-60 years (median: 52 ). All of them had the duration of symptoms shorter than 3 months. In 1 case there was progression observed in the form of local recurrence and metastases to the second lung and adrenal gland. $\mathrm{FEV}_{1}$ and VC $70-100 \%$ was noted in respectively 3 and 4 patients treated with lobectomy. Three (75\%) patients had endobronchial lesions observed in FOB. Patients treated with non-anatomical resection were at the age of 28-64 years (median: 54). None of the patients had hemoptysis symptoms. Half of the patients had progression in the form of local recurrence. $\mathrm{FEV}_{1}$ and VC $>70 \%$ was noted in $83 \%$ of patients. In FOB there was no bronchial pathology.

There was no statistically significant difference in PFS between anatomical and non-anatomical resection $(p=0.34)$. Progression-free survival of patients treated with non-anatomical resection did not significantly differ in comparison with patients treated with lobectomy $(p=0.91)$ and pneumonectomy $(p=0.20)$. There was no statistically significant influence of prognostic factors characteristic of PPS and soft tissue sarcoma (STS) on OS and PFS due to type of surgery (pneumonectomy, lobectomy and non-anatomical resection) $(p>0.05)$.

Due to the small analyzed group the statistical analysis was limited.

\section{Discussion}

Primary pulmonary sarcomas are a diverse group of rare non-epithelial malignant lung tumors in which it is hard to identify lung sarcoma based on either small biopsy samples from bronchoscopy, core or fine needle aspiration or even intraoperative investigation. The standard strategy of treatment in this type of tumor is similar to lung cancer. Lobectomy and pneumonectomy are still a gold standard in surgical treatment of PPS [1-6]. The medical literature is usually limited to reports based on single cases but analyses concerning larger group (i.e. 18-24 patients) have usually focused on the 5 -year OS rate and prognostic factors related to it [1-6]. These analyses showed factors affecting 5 -year OS of patients treated with surgery of PPS such as gender, radicalism of resection, size of tumor, degree of histological malignancy and TNM stage lung cancer.

Overall survival of patients who underwent radical treatment is better [1-6], but these studies do not show OS- and PFS-influencing factors that were dependent on the extent of the surgical treatment.

In our study OS of patients depended on the range of surgical treatment. Although statistical analysis of the studied group of patients treated with $\mathrm{RO}$ resection did not show the relations between OS, PFS and prognostic factors, there were noted similar correlations as in our previous analysis of 22 patients treated with surgical treatment [7]. Patients who underwent non-anatomical resection had a better prognosis. Median survival of these patients was 213 months, while in other cases it was only 12 months $(p=0.0001)$. Five-year survival in patients treated with non-anatomical resection was $83 \%$ vs. $6 \%$ for other procedures, and 10 -year survival was $67 \%$ in patients with nonanatomical resection.

This sort of surgery was performed mainly in patients with small peripheral tumors. The median value of the biggest dimension in this subgroup was $3.5 \mathrm{~cm}$, in one case reaching a maximum of $19 \mathrm{~cm}$. In this subgroup of patients the diagnosis was not established before surgical treatment. Intraoperative examination did not deliver a diagnosis of sarcoma, either, and examination of postoperative specimens indicated radical surgery. In this subgroup none of the patients reported hemoptysis, and most of them were women (83\%). In multifactorial analysis the risk of death in women was nearly 7 times lower than in men with diagnosed PPS [7]. Disease recurrence after non-anatomical resection manifested exclusively as local recurrence, and was diagnosed late; median PFS was 36 months vs. 12 months in anatomical procedures. All cases of local recurrence after non-anatomical resection were treated with surgery. The analysis conducted by Janssen et al. did not investigate the link of OS with non-anatomical sort of resection; however, patients in whom tumor enucleation was performed had longer survival compared to the median for the whole group reported by this author [3]. It is hard to find good reasons to explain such a long survival in this patient subgroup. It may be assumed that since patients treated with non-anatomic resection did not meet surgical standards of pulmonary parenchymal cancer (despite the surgical margin free of sarcoma), they were controlled more frequently, which made it possible to treat progression with surgery at an earlier time. The operator's intention was a diagnostic excision, but as no proof of malignancy was obtained, and pathomorphological examination revealed that primary surgery was radical, in consequence extension of surgery was abandoned.

Also, the results of this analysis may be inaccurate due to the low number of patients. The small sample size accounts for the lack of similar publications in the medical literature.

In this study patients treated with pneumectomy had a worse prognosis, likely due to the local stage of the disease: all tumors in this subgroup were bigger than $5 \mathrm{~cm}$, caused bronchial lesions, and in one case there was tumor spread to the left cardiac atrium. The patients were all men in this group; in half of the cases hemoptysis was reported. This symptom is common for more advanced tumors with bronchial invasion. The presence of hemoptysis increased the death risk almost 41 times in the group analyzed. All tumors were high graded in these patients, classified as stage III STS. Median PFS in pneumectomy patients was 
A

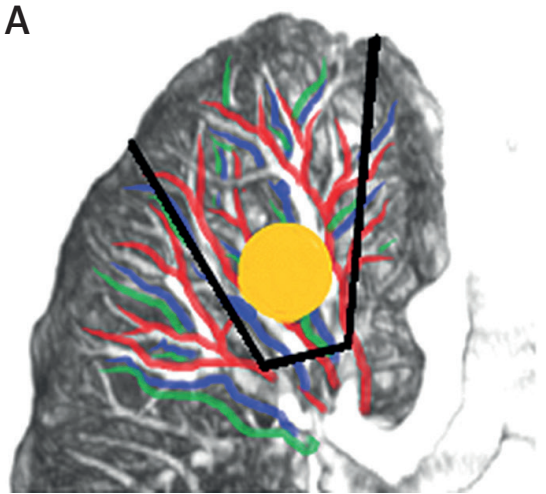

B

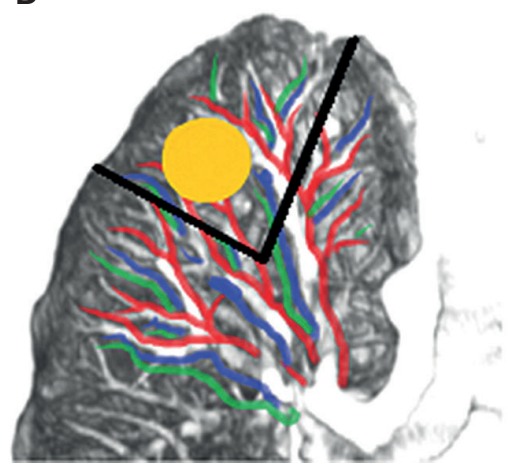

C

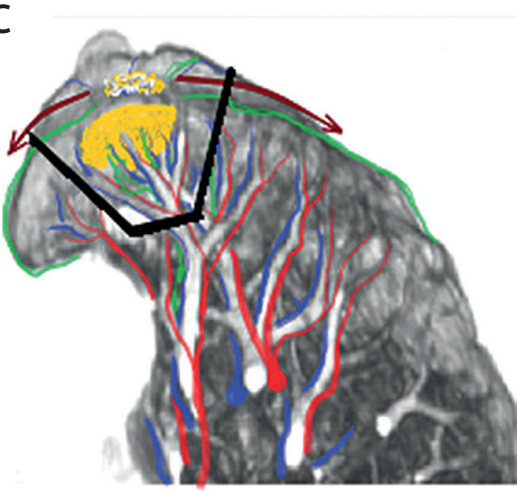

Fig. 3. Dependence of local recurrences on location and size of tumor in non-anatomical resections of lung cancer

7 months. Disease progression after this kind of surgery manifested only as distant metastases. In the treatment of metastases surgery was impossible to perform; chemoand radiotherapy were introduced in these patients.

What drew our attention was the increased number of local recurrences after non-anatomical resections, despite the fact that surgical margins were tumor free $\left(R_{0}\right)$. It is consistent with the opinion on treatment outcomes of soft tissue sarcomas in other locations. Non-anatomical resections of soft tissue sarcomas or those with a small surgical margin are more vulnerable to recurrences. Hasley et al. [8] showed a dependence of local recurrences on surgical margins in limb sarcoma resections. Local recurrences were more common in cases of a positive surgical margin (75.76\%) or marginal $(50.48 \%)$ than where the margin was wide or in anatomical resections (7.22\%) ( $p=0.001)$. Meade et al. pointed out the possibility of a larger number of local recurrences after non-anatomical resections of hemangiopericytoma [9]. In a report by Janssen et al., local recurrences appeared in both patients after enucleation of the tumor [3]. It correlates with our observation that 50\% $(n=6)$ of local recurrences occurred after non-anatomical resections.

Local recurrences after surgical treatment of PPS, due to small groups, are not a subject of analysis. However, we found similarities to effectiveness of non-anatomical resections of lung cancer. Schuchert et al. demonstrated a relation between the frequency of local recurrence and size of the tumor, as well as size of the surgical margin. Ratios of surgical margin to diameter of the tumor above 1 were correlated with a significantly lower percentage of recurrences in comparison to ratios below 1 (6.2\% vs. $25.0 \%, p=0.0014)$ [10].

Likewise, in analyses by Nishio et al. and Asamura et al. of treatment outcomes of wedge resection vs. segmental resection, they observed an increased percentage of local recurrences in relation to size of the tumor subjected to wedge resection of lung cancer ( $\mathrm{T} 1 \mathrm{a} / \mathrm{T} 1 \mathrm{~b})$. In the period of these clinical trials, no surgical treatment criteria had been established yet [11, 12].

Lung cancer subjected to non-anatomical resection located near the lung cavity (Fig. $3 \mathrm{~A}$ ), with a small surgical margin (Fig. 3 B), or infiltrating pulmonary pleurae (Fig. 3 C) - has a risk of local recurrence (Fig. 3).
Our observations indicate that there might be similarities in spread of PPS and local invasion of lung cancer.

Soft tissue sarcomas in locations other than the lung rarely spread though the lymphatic system. In the case of limb sarcomas, metastasis to lymph nodes only occurs in $2 \%$ to $6 \%$ of patients [13-15]. In our group we did not record metastasis to lymph nodes. However, in the Regnard et al. study metastases to N2 and N1 lymph nodes were recorded in 5 patients who underwent surgical treatment $(25 \%$, $n=20)$ [4]. Bacha et al. reported $6(26 \%, n=23)$ metastases to lymph nodes [5]. In the analysis of 365 patients from the Surveillance, Epidemiology, and End Results (SEER) database of the U.S. National Cancer Institute, Spraker [16] identified $58(16 \%)$ patients with metastases to mediastinal lymph nodes. These findings might suggest that sarcomas primarily located in lungs spread in a different way than those in different locations.

\section{Conclusions}

Five-year OS of patients who underwent non-anatomical resections of PPS is significantly higher than those who underwent anatomical resections. Patients who underwent non-anatomical resections of PPS were at higher risk of local recurrences. The high percentage of local recurrences after non-anatomical resections and significantly increased invasion of lymph nodes in PPS might indicate that it spreads in a similar way to lung cancer.

\section{Disclosure}

The authors report no conflict of interest.

\section{References}

1. Nascimento AG, Unni KK, Bernatz PE. Sarcomas of the lung. Mayo Clin Proc 1982; 57: 355-359.

2. McCormack PM, Martini M. Primary sarcomas and lymphomas of the lung. In: Thoracic Surgery: Frontiers and Uncommon Neoplasms. Vogt-Moykopf MN (ed.). CV Mosby, St. Louis 1989; 261-283.

3. Janssen JP, Mulder JJS, Wagenaar SS, Elbers HRJ, Van Den Bosch JMM. Primary sarcoma of the lung: a clinical study with long term follow-up. Ann Thorac Surg 1994; 58: 1151-1155.

4. Regnard JF, Icard P, Guibert L, Thomas de Montpreville V, Magdalenat P, Levasseur P. Prognostic factors and results after surgical treatment of primary sarcomas of the lung. Ann Thorac Surg 1999; 68: 227-231. 
5. Bacha EA, Wright CD, Grillo HC, Wain JC, Moncure A, Keel SB, Donahue DM, Mathisen DJ. Surgical treatment of pulmonary sarcomas. Eur J Cardiothorac Surg 1999; 15: 456-460.

6. Porte HI, Metois DG, Leroy X, Conti M, Gosselin B, Wurtz A. Surgical treatment of primary sarcoma of the lung. Eur J Cardiothor Surg 2000; 18: 136-142.

7. Gołota J, Osowiecka K, Orłowski T. Primary pulmonary sarcoma - long term treatment outcomes and prognostic factors. Kardiochir Torakochir Pol 2018; 15: 162-169.

8. Hasley I, Gao Y, Blevins AE, Miller BJ. The significance of a "close" marigin in extremity sarcoma; a systematic revive. lowa Orthop J 2018; 38: 123-130.

9. Meade JB, Whitwell F, Bickford BJ, Waddington JKB. Primary hemangiopericytoma of the lung. Thorax 1974; 29: 1-15.

10. Schuchert MJ, Pettiford BL, Keeley S, D'Amato TA, Kilic A, Close J, Pennathur A, Santos R, Fernando HC, Landreneau JR, Luketich JD, Landreneau RJ. Anatomic segmentectomy in the treatment of stage I non-small cell lung cancer. Ann Thorac Surg 2007; 84: 926-933.

11. Nishio W, Yoshimura M, Maniwa Y, Kitamura Y, Tane K, Takenaka D, Adachi S. Re-assessment of intentional extended segmentectomy for clinical T1aNO non-small cell lung cancer. Ann Thorac Surg 2016; 102: 1702-1710.
12. Asamura H, Hishida T, Suzuki K, Koike T, Nakamura K, Kusumoto M, Nagai K, Tada H, Mitsudomi T, Tsuboi M, Shibata T, Fukuda H; Japan Clinical Oncology Group Lung Cancer Surgical Study Group. Radiographically determined noninvasive adenocarcinoma of the lung: survival outcomes of Japan Clinical Oncology Group 0201. J Thorac Cardiovasc Surg 2013; 146: 24-30.

13. Fong Y, Coit DG, Woodruff JM, Brennan MF. Lymph node metastasis from soft tissue sarcoma in adults. Analysis of data from a prospective database of 1772 sarcoma patients. Ann Surg 1993; 217: 72-77.

14. Riad S, Griffin AM, Liberman B, Blackstein ME, Catton CN, Kandel RA, O'Sullivan B, White LM, Bell RS, Ferguson PC, Wunder JS. Lymph node metastasis in soft tissue sarcoma in an extremity. Clin Orthop Relat Res 2004; 426: 129-134.

15. Mazeron JJ, Suit HD. Lymph nodes as sites of metastases from sarcomas of soft tissue. Cancer 1987; 60: 1800-1808.

16. Spraker MB, Bair E, Bair R, Connell PP, Mahmood U, Koshy M. An analysis of patient characteristics and clinical outcomes in primary pulmonary sarcoma. J Thor Oncol 2013; 8: 147-151. 